BOEKEN, CONFERENTIES EN MEDIA

/ BOOKS, CONFERENCES AND MEDIA

JOSEPH HANLON, "MOZAMBIQUE: DE REVOLUTIE IN DE VERDRUKKING"

Nijmegen, Stichting Derde Wereld Publicaties, $1985,320 \mathrm{blz}$. ISBN 90-70230-16-X

Oorspronkelijke titel : Mozambique : the evolution under fire. London, Zed Press, 1984.

\title{
INLEIDING
}

Mozambique werd onafhankelijk in juni 1975, na een tienjarige bevrijdingsoorlog tegen het Portugese kolonialisme, dat zich tot dan had vastgeklampt aan de mythe van haar "overzeese provincies". De nieuwe regering, gevormd door de bevrijdingsbeweging FRELIMO (Frente de Libertaçao de Moçambiquel opteerde voor een socialistische ontwikkelingsweg, vanaf 1977 officieel omgedoopt tot Marxisme-Leninisme. Aldus vervoegde Mozambique de rangen van andere Afrikaanse landen, die zichzelf reeds eerder hadden bekeerd tot het "wetenschappelijk socialisme" (Congo, 1969 ; Somalie, 1970 ; Benin, 1974 ; Madagascar, 1975 ; Ethiopie, 1976 ; Angola, 1977).

Gelet op de grote verschillen tussen deze Afro-Marxistische landen, rees de vraag hoe Mozambique de gekozen basisoptie zou doordrukken, hoe de radikale breuk met het verleden zou verwezenlijkt worden? Welke prioriteiten zouden de bovenhand halen, in de economische sfeer (staatscontrole of prive initiatief), in de politieke sfeer (democratie of autoritair centralisme), in het buitenlands beleid ("nietgebondenheid", ontwikkelinghulp, regionale politiek) ? Welke sociale formaties zouden de lakens naar zich toe trekken? Welke vooruitgang zou geboekt worden in de strijd tegen de onderontwikkeling?

Tien jaar na de onafhankelijkheid verkeert Mozambique in een catastrofale situatie : burgeroorlog (met het MNR of Renamo 
- Resistencia Nacional Mocambicana), algemene destabiliteit, hongersnood, economisch bankroet. Het Frelimo heeft of dit ogenblik een kleiner deel van het land onder controle dan de Portugezen in 1974. De blinde terreur van het MNR (aanslagen, overvallen, economische sabotages, ontwrichting van het transport, vernietiging van gemeenschapsdorpen, graanopslagplaatsen, enz.) reikt reeds tot de nabije omgeving van de hoofdstad. Maputo. Men kan gemakkelijk gissen welke desastreuse gevolgen een dergelijke situatie teweegbrengt voor de ontwikkeling van het land, en in het bijzonder voor de agrarische produktie en voedselvoorziening, temeer daar natuurlijke rampen zoals droogte en overstromingen ook niet uitbleven.

Welke verklaringen of conclusies vastknopen aan deze evolutie sinds de onafhankelijkheid? Velen zijn ongetwijfeld geneigd de mislukking volledig aan het marxistisch dirigisme van het Frelimo toe te schrijven. Dergelijke selectieve interpretatiemethodes treft men steeds meer aan in actuele politieke analyses, waar uiterst complexe realiteiten verklaard worden aan de hand van a priori's of dogmatische schema's. Zo bv. op het gebied van de ontwikkelingssamenwerking, waar een aantal donors de mislukking van talrijke hulpprogramma's eenzijdig toeschrijven aan het falen van Afrikaanse regeringen (corruptie, ondoordacht beleid, gebrek aan absorptive capacity, enz.) en gemakshalve de koloniale erfenis vergeten, de negatieve invloed van de wereldrecessie onderkennen, of nalaten het eigen ontwikkelingsbeleid kritisch door te lichten.

Het boek van Joseph Hanlon bezondigt zich niet aan zo'n opstelling. Het biedt een uitstekend totaalbeeld van de specifieke koloniale voorgeschiedenis, de bevrijdingsstrijd en de ontwikkelingen na de onafhankelijkheid. Alleen in een globale context past een balans van tien jaar Frelimo-beleid, of kan de huidige situatie gevat worden. 
De grootste troeven van het boek zijn de inhoudelijke volledigheid, de genuanceerde opstelling van de auteur en de zeer concrete, hat journalistieke, aanpak van het onderwerp.

\section{Inhoudelijke volledigheid}

Alle hoofdlijnen en determinanten van het groeiproces naar de huidige politieke en economische situatie toe, komen aan bod. Vooreerst wordt de heel specifieke aard van het Portugese kolonialisme beklemtoond. Weliswaar dateert de Portugese aanwezigheid in Mozambique reeds van de 16 de eeuw, maar door de structurele zwakte van zijn economie kon Portugal zijn kolonies nooit zelf effectief besturen of hen minimale ontwikkeling bezorgen. Hanlon schetst op een boeiende wijze de gevolgen van deze koloniale politiek : de verpachting van Mozambique aan buitenlandse ondernemingen, de "dienstverlenende" bestemming van de economie (ten voordele van de buurlanden Zuid-Afrika en Rhodesie), de Portugese bevolkingskolonisatie (gesubsidieerde emigratie van arme boeren en winkeliers). het "recruteren" van lokale arbeidskrachten, het organiseren van dwangarbeid (o.a. voor de katoenteelt), en de onderdrukking van elk verzet (door militaire strijd, geheime politie, pasjeswetten, avondklok, enz.). Aangezien de Salazardictatuur in Portugal weinig liberalisering toeliet en de zwakheid van de Portugese economie een "neokoloniale" oplossing belette, bleef het moederland, met Navo-steun, een militaire oplossing nastreven, tegen het Frelimo.

Het baart dan ook geen verwondering dat bij de onafhankelijkheid, kolonisten in paniek wegvluchtten, half afgebouwde torenflats achterlatend waarvan de eerste steen nauwelijks een of twee jaren tevoren was gelegd.

Parallel hiermee beschrijft Hanlon het ontstaan en de evolutie van de bevrijdingsbeweging Frelimo, met bijzondere aandacht voor de strategische keuze voor gewapende strijd en voor de politieke conflicten, tussen burgerlijke en radicale tendenzen. Weergegeven wordt hoe de radicaliserig van het Frelimo een gevolg is van de talrijke praktische 
problemen, waarmee het bestuur van de "bevrijde gebieden" gepaard ging. De belangrijkste conflictpolen, waarrond zich de politieke lijnen ontwikkelden zijn racisme, regionalisme, "tribalisme", sociaal-economische verhoudingen, positie van de vrouw en onderwijs. Een concrete vraagstelling : voerden het Frelimo en de boeren strijd tegen de Porugezen "om de kleur van hun uitbuiters" te veranderen of werd een maatschappij met nieuwe sociaal-economische verhoudingen betracht?

Daaruit blijkt hoe de keuze voor een socialistische ontwikkelingsweg niet lukraak en modieus genomen werd bij de onafhankelijkheid, maar voortvloeide uit een langdurige interne strijd (Hanlon noemt het een "klassenstrijd").

De auteur besteedt verder aandacht aan de talloze moeilijkheden bij de uitvoering van de ambitieuze herstructureringen. Het utopisch karakter van de gekozen beleidsopties, in de gegeven omstandigheden, ligt aan de basis van de meeste mislukkingen. Zo werd vol revolutionair voluntarisme verklaard dat Mozambique binnen de tien jaar "een overwinning op de onderontwikkeling" zou verwezenlijken, door een tiennjarenplan (1980-1990). geprogrammeerd op een jaarlijkse groei van het BNP met 17 $\%$, en uit te voeren door grootschalige staatsinerventies in landbouw en industrie. Dit tienjarenplan is steeds dode letter gebleven. Reeds voor de periode 1982-85 werd een alternatief driejarenplan klaargestoomd, waarvan de doelstellingen drastisch werden ingeperkt. Bij deze oefening moest het Frelimo wel toegeven hoezeer het de eigen mogelijkheden inzake planning, organisatorisch kader. infrastructuur en middelen had overschat en hoezeer het de afhankelijkheid t.o.v. de wereldeconomie en de geringe aantrekkingskracht voor buitenlandse investeringen had onderschat. Bovendien kenmerken deze "geplande transformaties" zich door een voortdurend touwtrekken over beleidslijnen, en de richting en omvang van de veranderingen. Hanlon illustreert deze krachtmetingen in verschillende sectoren. Hij verwijst onder meer naar de vraag hoe de "socialisatie van het platteland" moet geschieden. Over de jaren heen merkt men bij het Frelimo diverse beleidsverschuivingen terzake, die getuigen van een 
pendelbeweging tussen steun aan grote staatsbedrijven enerzijds of steun aan boerencoöperaties en familielandbouw anderzijds. Het "nationaliseren en socialiseren" van de gezondheidszorg levert ook talrijke conflicten op, onderling verstrengeld, zoals deze tussen stad en platteland, kuratieve of preventieve aanpak, m.b.t. de status van de arts (en de tewerkstelling ervan op het platteland), of over de toepassing van het principe van "gelijke" behandeling (met de strijd om speciale privileges).

Interessant is ook de wijze waarop de auteur het vraagstuk van de democratie in Mozambique benadert. Het Frelimo heeft steeds look na zijn omvorming tot "marxistischleninistische voorhoedepartij") belang gehecht aan "volksmacht" en "massamobilisatie". Daarvan getuigen de "Grupos Dinamizadores" (comités ad hoc opgezet in dorpen, stadswijken, fabrieken, die ontelbare functies vervulden bij de ineenstorting van de koloniale structuren), de "productieraden", organisaties voor vrouwen en jongeren en de op diverse niveaus verkozen volksvergaderingen. Deze massa-organisaties werden beschouwd als de "verbindende schakels tussen de Partij en het volk, en dit volgens het principe van het "demokratisch centralisme". De grondwet sluit hierbij aan en stelt dat "de macht berust bij de arbeiders en de boeren, verenigd en geleid door het Frelimo". Een en ander kan evenwel niet beletten dat de machtsstrijd tussen de verschillende sociale formaties uiteindelijk bepaalt hoe de revolutie zich institutionaliseert. Ten bewijze : het Frelimo moet talrijke "niet-geplande" evoluties vaststellen, zoals de groeiende ongelijkheid tussen arme en rijke boeren, de mislukte "coalitie tussen boeren en arbeiders" en de ontwikkeling van een "bourgeoisie" uit de bureaucratie en de particuliere handel.

De geopolitieke context van Mozambique wordt grotendeels bepaald door de verhouding met het buurland Zuid-Afrika, gekenmerkt door sterke economische afhankelijkheid en politieke destabilisatie (door Zuid-Afrikaanse openlijke of bedekte steun aan het MNR). Veranderingen hierin zijn afhankelijk van de vooruitgang van de regionale samenwerking in het raam van de SADCC (Southern African Development 
Coordination Conference, opgericht in 1980, met als leden : Angola, Botswana, Lesotho, Malawi, Mozambique, Swaziland, Tanzania, Zambia, Zimbabwe), enerzijds, en van de uiteindelijke toepassing van het "Nkomati-akkoord" anderzijds. Laatstgenoemd "niet aanvalsverdrag en overeenkomst van goed nabuurschap" (lees ook : nietinmenging in binnenlandse aangelegenheden), in maart 1984 gesloten tussen Zuid-Afrika en Mozambique, heeft totnogtoe geenszins de verwachtingen ingelost en voor Mozambique noch vrede, noch economische voordelen opgebracht. Tegen de bepalingen in van het verdrag blijft Zuid-Afrika het MNR bedekt steunen. Op te merken valt overigens dat Hanlon een merkwaardig gedetailleerd overzicht biedt van het MNR, een vrij moeilijk te catalogiseren oppositiebeweging. Deze was oorspronkelijk opgezet door de Rhodesische Veiligheidsdiensten en wordt nu actief gesteund en in het leven gehouden door Zuid-Afrika. De beweging is samengesteld door een heterogene groep "ontevredenen", waardoor de kernvraag rijst of het MNR een oppositie is met een legitieme grondslag (met een politieke visie, een achterban), of louter "gewapende bandieten" groepeert zoals de Mozambiquaanse propaganda hen afschildert look letterlijk, op de talloze originele muurschilderingen van Maputo). In elk geval wordt het MNR steeds meer "getolereerd" of actief ondersteund door een bange boerenbevolking...

"Balancerend tussen Oost en West" typeert voor het overige het buitenlands beleid t.o.v. de grootmachten. Aanvankelijk leek een strikt bondgenootschap in de maak met de SovietUnie, maar door wederzijdse onenigheden koelde de verhouding af. De Soviet-Unie kreeg geen militaire basis en Mozambique te weinig kapitaalhulp en geen lidmaatschap bij de Comecon, ondanks de steun van Bulgarije en OostDuitsland. Daarentegen verbeterden de relaties met het Westen, mede onder invloed van de economische chaos. Mozambique werd tot allerhande toegevingen gedwongen en zocht toenadering tot de EG, de Wereldbank en het IMF. Teken des tijds : nu heet de Sovjet-Unie niet langer de "natuurlijke bondgenoot" maar veeleer de "traditionele vriend". Uitstekende verhoudingen heeft Mozambique steeds 
gehad met de Scandinavische lanen, Nederland, OostDuitsland, Bulgarije en Cuba.

\section{Opstelling van de auteur}

Alhoewel een zekere sympatie voor de Mozambiquaanse revolutie voelbaar is, toch leidt zulks niet tot bewust geheugenverlies bij het vaststellen van beleidsfouten, verlammende contradicties en negative evoluties in het Frelimo. De voorbeelden hiervan zijn legio. Zo krijgt de geleidelijke afbrokkeling van de de democratische overtuigingen van het Frelimom naarmate de crisis toeneemt, alle aandacht. Uitingen van het groeiend autoritarisme zijn o.a. de uiterst srenge nieuwe wetten (doodstraf voor economische delicten, executies in net openbaar), herinvoering van de stokslagen in het openbaar, kordate verwijdering van werklozen uit de steden ('Operatie Productie'), pasjeswetten, die de bewegingsvrijheid van het individu bepalen: De auteur schuwt een beperkte vergelijking met Zuid-Afrika niet.

\section{De vorm}

Wellicht als gevolg van zijn vijfjarig verblijf in Mozambique, als correspondent voor o.a. de BBC. The Guardian en The Observer, heeft Hanlon gekozen voor een bijzondere aanpak van de materie. Hierdoor krijgt de lezer een verfrissende mengeling aangeboden van o.a. theorievorming, officiele standpunten, interviews, getuigenissen, anekdotes, krantenuittreksels, eigen ervaringen ; dit alles in een vlotte stijl uitgewerkt. Wie echter op zoek is naar uitgebreid bronnenmateriaal en naar een literatuuroverzicht komt minder aan bod.

\section{BESLUIT}

De titel van het boek "De revolutie in de verdrukking" geeft misschien meteen antwoord op de hamvraag : is in 
Mozambique een socialistische ontwikkelingsweg mogelijk?

Kort na de onafhankelijkheid beschouwden velen Mozambique als een testcase voor het Afro-Marxisme. Op papier beschikte het regime ongetwijfeld over een aantal uitzonderlijke troeven : een leiding met een sterke interne cohesie en legitimiteit, toegewijd aan de revolutionaire zaak (weinig corruptie en zelfverrijking), bereidheid tot zelfkritiek, democratische ingesteldheid, enzomeer. Tien jaar na de afhankelijkheid wankelt de Frelimo-leiding evenwel en lijkt de revolutie een halt toegeroepen, laat staan teruggeschroefd. Bij het vellen van een oordeel over de effectiviteit van Mozambique's ontwikkelingsopties, wordt het beeld vertroebeld door de catastrofale erfenis, de natuurlijke rampen, de hoge kostprijs van de destabilisatieen sabotagepolitiek van het MNR (en Zuid-Afrika), zodat het uiterst moeilijk is alle factoren naar hun juiste waarde te schatten. Bepalend voor de toekomst van het land is de mate waarin het Frelimo er in zal slagen een evenwicht tot stand te brengen tussen economische vooruitgang (met alle toegevingen vandien), de neutralisering van de MNR-dreiging en het behoud van de gekozen ontwikkelingsweg.

De dood in tragische omstandigheden van president Samora Machel, een decennium lang charismatisch bezieler van de Mozambiquaanse revolutie, heeft de politieke situatie er niet eenvoudiger op gemaakt. Zijn opvolger Joaquin Chissano, eveneens een 'oudstrijder' van het Frelimo, kan evenwel nog steeds steunen op een eensgezinde bewindsploeg. Bovendien kan zijn meer pragmatische ingesteldheid de noodzakelijke realpolitieke openingen in de ontwikkelingsideologie bewerkstelligen. Zoals in Tanzania misschien, waar het vertrek van president Nyerere kon leiden tot een nieuwe verstandhouding met het IMF.

Bespreking door:

Jean BOSSUYT

Galgenberg 34

9000 Gent 